PALEO

Revue d'archéologie préhistorique

$23 \mid 2012$

Varia

\title{
Gabriel Mérignargues (1928-2012)
}

Jean-Jacques Cleyet-Merle and Antoine Chancerel

\section{(2) OpenEdition}

\section{Journals}

Electronic version

URL: http://journals.openedition.org/paleo/2482

DOI: 10.4000/paleo.2482

ISSN: $2101-0420$

\section{Publisher}

SAMRA

\section{Printed version}

Date of publication: 15 December 2012

Number of pages: 9-10

ISSN: 1145-3370

\section{Electronic reference}

Jean-Jacques Cleyet-Merle and Antoine Chancerel, « Gabriel Mérignargues (1928-2012) », PALEO

[Online], 23 | 2012, Online since 16 July 2013, connection on 10 August 2020. URL : http:// journals.openedition.org/paleo/2482 ; DOI : https://doi.org/10.4000/paleo.2482

This text was automatically generated on 10 August 2020.

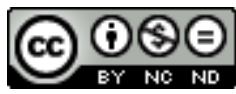

PALEO est mis à disposition selon les termes de la licence Creative Commons Attribution - Pas d'Utilisation Commerciale - Pas de Modification 4.0 International. 


\title{
Gabriel Mérignargues (1928-2012)
}

\author{
Jean-Jacques Cleyet-Merle and Antoine Chancerel
}

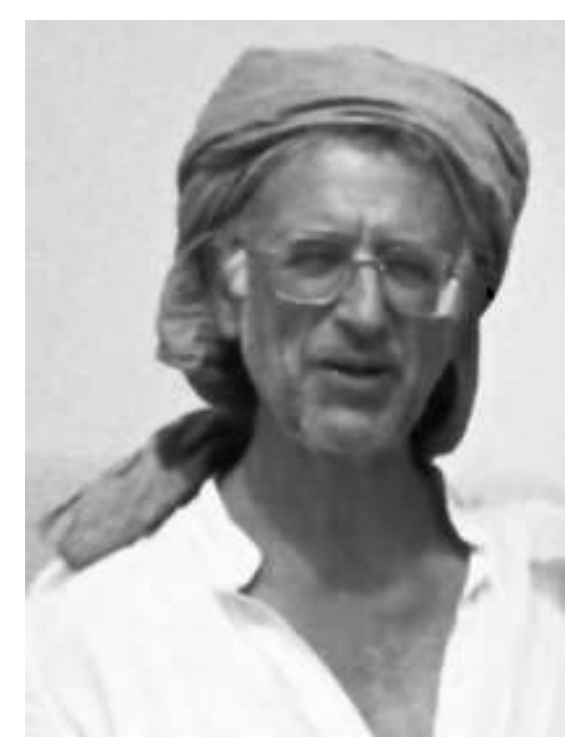

1 Gabriel Mérignargues was born in 1928, son of an artist. He was a very cultured doctor with a great sense of humanity, fascinated by history, politics, the arts, literature and poetry.

2 He performed his military service in the high plateaux in Algeria during the war years 1956-1957, in a SAS (Specialized Administrative Section), where he learned Arabic and stayed with and looked after the local "goumiers".

3 After his return to France he felt the urge to travel again and accepted a doctor's position in the Touggourt hospital in 1959 (oasis department in the Algerian Sahara), close to the people he loved. His passion for prehistory began at this time during expeditions in the desert. He loved the adventure and freedom of those wide open spaces and spent more and more time trekking further into the desert. He read widely to broaden his knowledge of Saharan prehistory and contacted the Bardo Museum in Alger to suggest collecting the prehistoric remains he encountered strewn across the 
desert. He then wrote up a summary of each site he discovered (El Alia, Hassi Daoula, Hassi Sareth...).

4 He returned to France after Algerian independence and decided to pursue his prehistory studies at the Sorbonne in Paris during the autumn of 1962. He then decided to settle in Eyzies-de-Tayac, in order to work as a general practitioner and stay in touch with his love for prehistory. He kept in contact with many Africanist prehistorians, namely Camps, Hugo, etc..., who helped him with his work.

5 He returned to work in Oran hospital in Algeria and undertook countless exploratory journeys in the Sahara between 1965 and 1972, during which he continued to collect lithic industries from new sites (such as Tan Elak) and sites that he had discovered previously.

6 After his retirement from Chambery hospital, he maintained links with Africa and personally helped African doctors to gain access to specialized studies, so that they could take charge of their country's destiny. He also participated in various humanitarian missions.

7 Gabriel Mérignargues had an insatiable passion for the past and although he was not a prehistorian, he adopted a very conscientious approach to his work. For this reason, he donated his collections and works to the Eyzies-de-Tayac Museum, so that they might be beneficial to research.

8 The National Prehistory Museum thus received several consequent donations between 1998 and 2005, all of which were unanimously accepted by the Acquisitions Commission of the national museums. Several figures reveal the amplitude of these donations: over 28,000 objects from 29 sites! Some of these sites, like Amguid (acquired in 2005) have yielded remarkable Lower Palaeolithic series (bifaces, cleavers, cores...). However, most of the collections are from recent prehistoric sites. Among the main sites, Tan Elak, which contains an exceptional series of grinding tools is worth a mention, as are the sites of Erg Ben Chaouli, Hassi Daoula (with 6,000 and 5,000 objects respectively) or Sidi Mahadi near Touggourt, which contains series from several periods (Capsian, Neolithic).

9 Gabriel Mérignargues also made generous donations to various other museums and institutes, in the domain of the arts, ethnography, etc... The word humanist springs to mind to evoke the engaging and generous personality of Gabriel Mérignargues and we extend our gratitude and compassion to his family. 
Dans le désert...

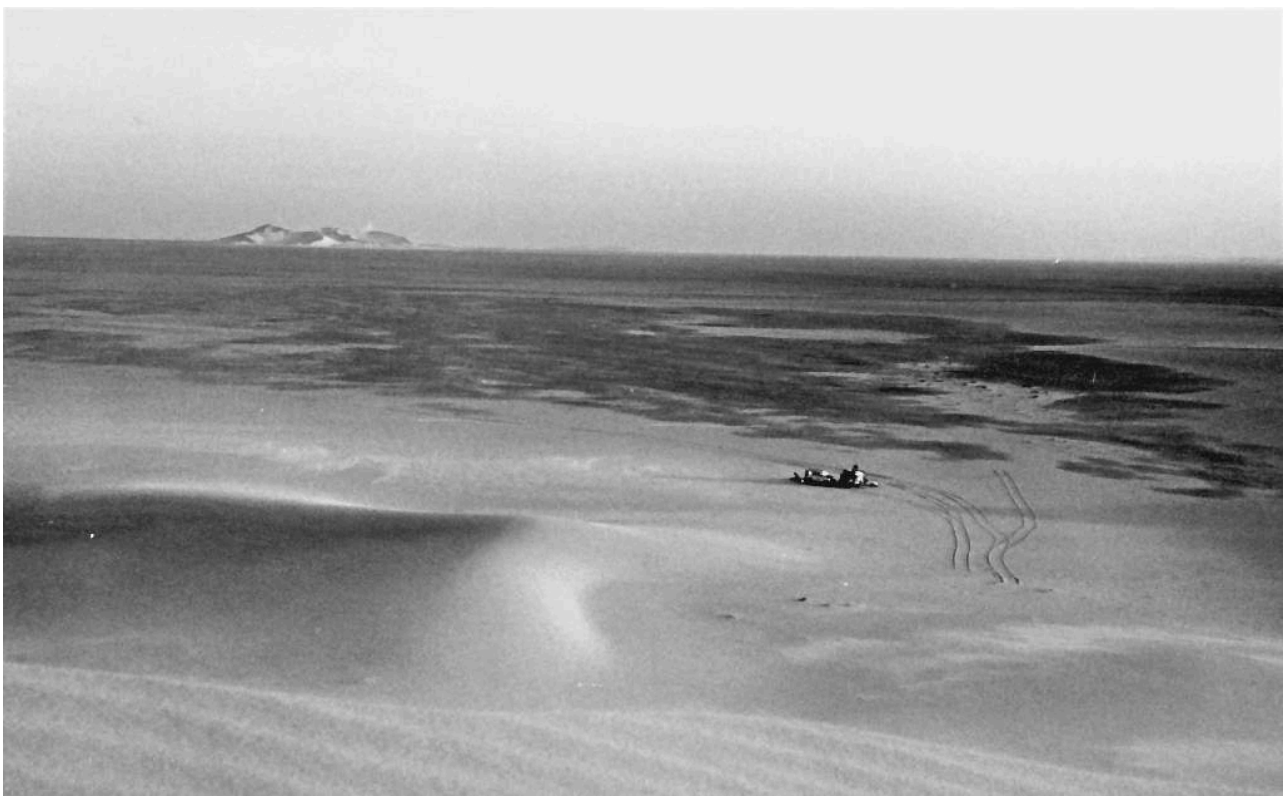

